\title{
The Current Situation and Development of Grain Storage Technologies and Facilities for Chinese Farmers
}

\author{
Fujun Li, Tianyu Shi, Yang Cao, Yi Wu and Lin Tian \\ Academy of State Administration of Grain, Beijing 10037, China
}

\begin{abstract}
In China, the quantity of farmer's grain storage covers about $40 \%$ of the total grain yield every year. While, the losses of farms' grain storage are up to $8 \%$, which is due to the lack of grain storage facility and technology. The losses of farmer's grain storage could reach nearly 20 million tons every year. In this paper, the current situation and development of grain storage technology and facility for Chinese farmers were presented. And a series of policy and research work for reducing the losses of farms' grain storage was introduced. The large scale farmers are now developing quickly in China, the new storage warehouse and mechanized facility should be developed adaptively. So, the new storage technology and policy to meet the need of large scale farmers were also introduced in this paper.
\end{abstract}

Key words: Farmer's grain storage, storage facility, reduce loss.

\section{Present Situation and Problems of Farmer's Grain Storage in China}

Since ancient times, Chinese farmers have formed the habit of reserving grain, food and clothing against war and natural disasters. After the grain harvest, many rural households give priority to store enough grain to feed their families in the whole year. In some regions, farmers even keep all the grain in granary. According to the data surveyed by State Administration of Grain, in recent years, the grain storage of national rural households was about $50 \%$ of the total grain output in every year, and the annual stocks have reached about 250 million tons [1]. The average grain storage was about $1,200 \mathrm{~kg}$ per rural household, but there is some difference in different regions, for example, Heilongjiang and Jilin province in northeast of China, which are the main producing areas, farmers keep more than 5,000 kg every year, and in Hainan province they keep about $500 \mathrm{~kg}$.

In most regions of China, because of poor facilities and low-level storage technology, the losses caused by

Corresponding author: Fujun $\mathrm{Li}$, chief engineer, associate professor, research fields: grain storage and transportataion technology. rodent, insect, mildew and other factors are very serious, especially in the main producing areas. According to the sampling survey by State Administration of Grain, the loss ratio of the national farmer's grain storage was $8 \%$ on average, and the annual grain loss was about 20 billion kg, equivalent to the grain output from a piece of fertile land of about 41 billion $\mathrm{m}^{2}$ [2]. The average loss ratio of different cereal about farmer's grain storage in China is shown in Table 1, and the causes are shown in Fig. 1. The region difference of farmer's grain storage losses is shown in Table 2.

What's more, the farmer's grain storage condition is poor and the application of the scientific grain storage technology is not enough. All these factors lead to an obviously decline in grain quality, even cause the pollution of the grain and bring great risks to grain quality and food safety.

An farmer's grain storage investigation was carried out in 2007 by the government department, which was focus on the main corn producing area Liaoning province in Northeast of China, the main wheat producing area Shandong province in the North China Plain, and the main paddy producing area Sichuan 
Table 1 The average loss ratio of farmer's grain storage in China.

\begin{tabular}{ll}
\hline Cereal & The average loss ratio of farmer's grain storage \\
\hline Corn & $11 \%$ \\
Paddy & $6.5 \%$ \\
Wheat & $4.7 \%$ \\
\hline
\end{tabular}

The hazard ratio of farmers' grain storage losses in China

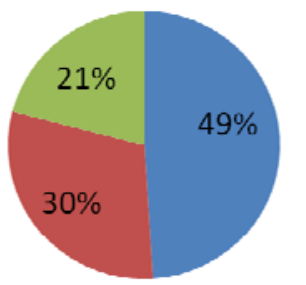

rodent

mildew

insect pests

Fig. 1 The hazard ratio of farmer's grain storage losses in China.

Table 2 The region difference of farmer's grain storage losses in China.

\begin{tabular}{ll}
\hline Region & $\begin{array}{l}\text { The average loss ratio of } \\
\text { farmer's grain storage }\end{array}$ \\
\hline Northeast of China & $10.2 \%$ \\
Northwest of China & $8.8 \%$ \\
The middle and lower reaches of & $7.4 \%$ \\
Yangtze River & $5 \%$ \\
Huang-Huai-Hai regions of China & 5\% \\
\hline
\end{tabular}

province in the Yangtze River Basin. In Liaoning province, more than 10 billion kg of grain were stored by farmers annually, accounting for $57 \%$ of the total grain output, and the main grain varieties were corn and paddy. $65 \%$ to $70 \%$ of the newly havest corn were stored more than three months by farmers annually, and the storage quantity in the whole province was about 7.3 billion kgs. $66 \%$ to $71 \%$ of the newly havest paddy were also stored more than three months by farmers annually, and the storage quantity in the whole province was about 2.8 billion kgs. The traditional method of farmer's grain storage in Liaoning province was very simple, such as storing the corn ears in simple wooden granary, or just stacking the corn ears on the ground, and storing the paddies in bags and stacking indoor. The poor grain storage methods caused a great loss after the harvest. The loss ratio of farmer's grain storage mostly caused by rodents, mildew, insects, and it can reach $8 \%$ to $15 \%$. If estimated by the minimum ratio, that was $8 \%$, The loss of farmer's annual grain storage in the Liaoning province would be about 800 million kgs, equivalent to the grain output from a piece of farmland of about 1.33 billion $\mathrm{m}^{2}$. The quantity of farmer's grain storage in Sichuan province was about 11.5 billion kgs, accounting for $36 \%$ of the total grain output in the whole province. The average quantity of grain storage per household was from 1,000 to 3,000 kgs. The main stored grain variety was paddy. Farmer's grain storage facilities were wooden cabinet, wooden barrel and bamboo utensil which could not qualify the requirements of thermal-insulation, air-tight, anti-rodents, anti-insects and anti-mildew, therefore were prone to be damaged by them. The loss ratio of farmer's grain storage was $8.6 \%$. If estimated by $8 \%$ averagely, the whole province would lose 900 million kgs of grain one year, equivalent to the grain output from a piece of farmland of 1.2 billion $\mathrm{m}^{2}$. The quantity of farmer's grain storage in Shandong province was about 20 billion kgs, accounting for 50\% of the province's total grain output. The main stored grain variety was wheat. The traditional method of grain storage was keeping grain in woven bags and stack, without the capability of anti-rodents, anti-insects and anti-moisture. According to the typical survey on 2,168 rural households in Shandong province by Shandong Grain Bureau in 2006, the households had grain storage of 2.35 million kgs. The average storage loss ratio was $6.7 \%$. The annual wheat loss of per household was about 63 kgs. Estimated by this, the annual wheat storage loss of farmers in Shandong province was about 1.3 billion kgs.

Comprehensively, the main causes of the great loss of farmer's grain storage are as follows: First, the farmer's grain storage facilities were too simple and crude; Second, the damages of rats, birds, insects and mildew were serious; Third, farmers usually did not have the basic knowledge and the practical technical measures to prevent and control insects and mildew; 
Forth, postharvest departments and enterprises did not provide enough technical support and service. Therefore, it's an urgent task to research and develop the advanced and practical grain storage facilities, to give enough technology support and training of grain strorage for farmers. All these measures would improve the conditions and the technical level of farmer's grain storage, and would increase the output and income for the farmers, and will ensure the national food safety [3].

\section{Granary R\&D and Application for Farmer's Grain Storage in China}

In order to improve farmer's grain storage technology in China, the primary task is to carry out $R \& D$ of the granary facility of the grain storage. China launched the major project "Food production-increasing technology project" and the issue "Integration demonstration of farmer's scientific grain storage technology to reduce stored loss" in 2004 [4]. With the joint efforts of Chengdu grain storage research institute, Henan university of technology, and food research institutions in Liaoning, Heilongjiang, Hunan and other provinces, 10 kinds of advanced and practical farmer's grain storage facilities were developed, according to the grain storage characteristics of the three great plains in China, the Northeast Plain, the North China Plain and the Middle-lower Yangtze Plain. Since 2007, China has arranged the central subsidy and investment to carry out the special project of farmer's scientific grain storage. Before the summer harvest in 2011, nearly 2 million rural households from 25 provinces (including autonomous regions and municipalities), such as Liaoning, Jilin, Hebei, Shandong, Sichuan, Hunan, etc. had been equipped with new grain storage facilities. It was estimated that the 2 million sets of grain storage facilities would store about 4 billion kgs of grain, if calculated by $6.5 \%$ reducing loss ratio on average, therefore, it would reduce 260 million kgs of the grain storage loss annually, equivalent to an increase of
326.67 million $\mathrm{m}^{2}$ of farmland, and add an income of 500 million Yuan for farmers. By the implementation of the project and the role modle demonstration for householder's grian storage, farmers' traditional grain storage concept has been changed and they have gradually realized that the losses caused by insects, mildew and rats would not only lead to the quantity loss of grain, but also seriously influence the safety of grain quality. They became to realise that the farmer's scientific grain storage laid a foundation to ensure the national grain quantity and the quality safety.

By the implementation of the project, many news types of the grain storage granary were made for the farmers in different regions. In the main grain producing areas such as the North China Plain and the Middle-lower Yangtze Plain, the composable color plate granary and the galvanized steel plate granary were mainly adopted. The steel net rectangular granary and the steel net round granary were used in the Northeast China Plain. The wooden granary with metal skeleton were developed and promoted in Xinjiang.

According to "The construction standards of farmer's small granary" [5] and "The general atlas of farmer's small granary” issued by State Administration of Grain, farmer's small granaries are divided into the four categories by the building materials: the metal plate granary, the metal net granary, the polymer materials granary and the brick and concrete granary.

The metal plate granary is a kind of farmer's small granary mainly made of metal plates. These typical granaries include the composable color plate granary, the double color plate granary, the hot-dip galvanized or aluminized steel plate granary, etc. It's suitable for farmers in all regions to store paddies, wheat, corns, and other raw grain with safety moisture content.

The metal net granary is a kind of farmer's small granary mainly made of metal nets. These typical granaries include the round non-skeleton steel net granary, the round skeleton steel net granary, the 
rectangular steel skeleton granary, the wooden granary with skeleton metal net, etc. It's suitable for farmers to store maize cob with moisture content lower than 25\% in the northeast region and the east of Inner Mongolia Autonomous Region.

The polymer material granary is a kind of farmer's small granary mainly made from polymer materials. These typical granaries include the composable polyethylene plate granary, the glass fiber reinforced plastic granary, the PVC soft granary, etc. It's suitable for the farmers in all regions to store paddies, wheat, corns and other raw grain with safety moisture content.

The brick and concrete granary is a kind of farmer's small granary mainly made of bricks, concretes or precast reinforced concrete slab. These typical granaries include the general brick and concrete granary, the under-staircase brick and concrete granary, the cement board assembly granary, etc. It's suitable for the farmers in the southwest region to store paddies and other raw grain with safety moisture content.

At present, the capacity of the main granaries for small-scale farmers to store wheat, corns, paddies, and other raw grain are shown in Table 3.

Among the 2 million sets of the grain storage facilities manufactured during the special project for farmer's scientific grain storage, there are 1.15 million sets of the color plate assembly granary, which occupies 58\%. 350,000 sets of the rectangular steel skeleton granary are accounting for $18 \%$, 200,000 sets of the hot-dip galvanized or aluminized steel plate granary are accounting for $10 \%, 160,000$ sets of the steel net drying granary are accounting for 8\%, 100,000 sets of the wooden granary with skeleton metal net are accounting for $5 \%$.

\section{Technical Improvement Requirements and Practices of Farmer's New Grain Granaries}

During the large-scale promotion and application of the above granaries, in practice, every region had a series of technical improvements and innovations of farmer's small grain storage granaries according to the specific circumstances of grain varieties, storage habits, ecological condition for grain storage, etc., which were to make the granaries more optimized in some ways like function, material saving, convenience of storing grain, sturdiness and durability, etc. By improving the design and manufacturing process, the pipeline operations and the large-scale production have been achieved.

\subsection{Material Saving, Sturdiness and Durability}

Shandong Rizhao Guo'en Co., Ltd. chose the general plate to reduce the cost of materials. All the

Table 3 The main kinds of granary for small-scale farmers in China.

\begin{tabular}{|c|c|c|c|c|}
\hline Kind of granary & Materia and structure & $\begin{array}{l}\text { Volume } \\
\left(\mathrm{m}^{3}\right)\end{array}$ & Capacity & Area \\
\hline $\begin{array}{l}\text { The composable color plate } \\
\text { granary }\end{array}$ & $\begin{array}{l}\text { Made of single color plates, able to } \\
\text { be installed and folded in stack }\end{array}$ & 1.5 & $\begin{array}{l}1,500 \text { kgs of wheat or } 1,100 \\
\text { kgs of paddy with safety } \\
\text { moisture content }\end{array}$ & $\begin{array}{l}\text { North China Plain and } \\
\text { the Middle-lower } \\
\text { Yangtze Plain }\end{array}$ \\
\hline $\begin{array}{l}\text { The hot-dip galvanized or } \\
\text { aluminized steel plate } \\
\text { granary }\end{array}$ & $\begin{array}{l}\text { Made of the hot-dip galvanized or } \\
\text { aluminized steel plate, able to be } \\
\text { installed and folded in stack }\end{array}$ & 1.5 & $\begin{array}{l}1,000 \text { kgs of paddy with } \\
\text { safety moisture content }\end{array}$ & $\begin{array}{l}\text { North China Plain and } \\
\text { the Middle-lower } \\
\text { Yangtze Plain }\end{array}$ \\
\hline $\begin{array}{l}\text { The round skeleton steel net } \\
\text { granary }\end{array}$ & $\begin{array}{l}\text { Made of metal skeleton and metal } \\
\text { net, cylindrical }\end{array}$ & 14 & $\begin{array}{l}7 \text { tons of maize cob with } \\
\text { high moisture content }\end{array}$ & Northeast of China \\
\hline $\begin{array}{l}\text { The rectangular steel } \\
\text { skeleton granary }\end{array}$ & $\begin{array}{l}\text { Made of the metal steel skeleton and } \\
\text { metal net, rectangular }\end{array}$ & $12-22$ & $\begin{array}{l}6-10 \text { tons of maize cob with } \\
\text { high moisture content }\end{array}$ & $\begin{array}{l}\text { Liaoning, Jilin, } \\
\text { Heilongjiang and other } \\
\text { province }\end{array}$ \\
\hline $\begin{array}{l}\text { The wooden granary with } \\
\text { skeleton metal net }\end{array}$ & $\begin{array}{l}\text { Made of the wooden skeleton and } \\
\text { the metal net }\end{array}$ & 1.4 & $\begin{array}{l}1 \text { ton of wheat with safety } \\
\text { moisture content }\end{array}$ & $\begin{array}{l}\text { Xinjiang Autonomous } \\
\text { Region }\end{array}$ \\
\hline $\begin{array}{l}\text { The general brick and } \\
\text { concrete granary }\end{array}$ & $\begin{array}{l}\text { Made of a mixture of brick and } \\
\text { concrete }\end{array}$ & $1.5-3$ & $\begin{array}{l}1,000-2,000 \text { kgs of paddy } \\
\text { with safety moisture content }\end{array}$ & South of China \\
\hline
\end{tabular}


materials were from Wuxi United Iron and Steel Co., Ltd., and two kinds of color plates with the setting width of 1,000 mm and 1,200 mm were adopted. The color plates of 1,200 mm were employed in the lower part, the bottom and the cover of the granary; the color plates of $1,000 \mathrm{~mm}$ in the middle and upper part of the granary. At the same time, the company improved the supporting parts and fastened the seams connection. The cover was unitarily stamped and riveted of flat seams to enhance the stability. The polyethylene spiral grain outlet and the grain outlet with buckle cover were both convenient for the grain outlet. Inside the granary, polyethylene plastic bags were placed to achieve the airtight storage for wheat. The No. 12 iron wire with more than $300 \mathrm{~mm}$ meters long was used to wrap around the seams connection to improve the tensile strength of the granary. While in Zhejiang Taizhou Zhongsui Electrical Co., Ltd., the color plate composable granary was made of cold rolled sheet with a width of $0.6 \mathrm{~mm}$, which was unitarily stamped by Shanghai Baosteel Group Corporation. The grain outlet was equipped with the stainless steel tube, which was connected by welding, and the simple gate valve was equipped to switch easily and flexibly. The granary was overall sprayed to anti corrosion.

\subsection{Function Improvement for Easy Grain Storage}

Heilongjiang Zhongliang Storage Technology and Engineering Co., Ltd. developed two types of the round steel net granaries, JSWD-200 (with a capacity of $20 \mathrm{~m}^{3}$, holding 15 tons of corn kernels) and JSWD-500 (with a capacity of $50 \mathrm{~m}^{3}$, holding 37 tons of corn kernels), with more reasonable and strong structure. The granary was partially manufactured and assembled on site. The grain could be loaded from the outlet installed either on the side wall or on the top of the granary. The big capacity could satisfy the needs of farmer's grain storage in the northeast region. It could store maize cob, corn kernels and paddy with safety moisture content. Inside the granary JSWD-500-I, there was a ventilated duct for natural or mechanical ventilation. The color plate composable granary, produced by Zhejiang Taizhou Zhongsui Electrical Co., Ltd., added the ventilation ducts for ventilation and dehumidification. There were two floors in the bottom and the mezzanine, both were reinforced. The ventilation ducts were connected to outside. Inside the granary, the bottom plate was of ventilation holes and the covered with scattered pores for ventilation and dehumidification. Because of the high moisture, the grain was hard to store in gerneral, but now all these improved measures have fixed this problem.

\subsection{Pipeline Operations and Large-Scale Production}

Hebei Cangzhou Grain Machinery Factory combined the molds, the pneumatic equipment and the electric equipment together and designed three sets of molds. By the color plate stamping mold technology, the production process was integrated into pipeline operations, and the efficiency and automation of production were improved. The process of production line only took 45 seconds, which greatly reduced the workload. At the same time, the ways of production and distribution were changed. A production group was supported with 2 to 4 processing groups. The processed semi-finished products such as covers, cylinders, bottoms, etc. were transported to every processing group allocated near the farmers. Then the processing group assembled on site and then delivered the granaries to the farmers at home. Each automobile could hold 700 sets, therefore the transportation cost was greatly reduced. The fully automated production line invested by Hubei Jingmen Yewei Co., Ltd. could produce a small granary per minute. The cover and the bottom were formed by drawing die set. The cylinder was embossed and pressed with eight ribs around it, adopted the new vertical spinning technology, so that the stereo sense was strong and durable. At the bottom of the granary, 24 ribs were molded for ventilation and anti-moisture. The granary was fabricated by food grade PVC materials, which made it transparent 
enough to observe the situation of grain. Changchun Xuyang Group in Jilin province established a standardized production line to assemble granaries, with a capability of producing 200 sets of the rectangular steel skeleton granary every day.

\section{Prospect of $R \& D$ and P\&A of Farmer's Scientific Grain Storage Facilities}

With the constant improvement of R\&D and the larger-scale P\&A (promotion and application) of farmer's new grain storage facilities, the standard granaries such as the color plate assembly granary, the rectangular steel skeleton granary, the steel net drying granary, the wooden skeleton metal net granary, the hot-dip galvanized steel plate granary, etc. will play an important role on famer's grain storage. In the future, according to farmer's grain storage demands of different grain varieties in different regions, especially the large scale famers' demands after the intensive land management, the innovation and improvement of the grain storage granary types and the application of new materials should be accelerated. It is necessary to create more granary types with strict standard, scientifical grain storage function and lower cost.

\subsection{The Research on Granary Type and Technology} Should Be Continued and Strengthened to Implement the Serialization and Standardization of the Granary

Suitable granaries should be developed according to the intention and usage of farmer's grain storage in different regions to meet farmer's grain storage demands. In the northeast region, the farmers mainly store grains as commodity grain for three months or so. In the region of Yangtze River and south China, the farmers store grain mainly as rations and feed grain. Besides, because of the characteristics of temperature and humidity, the ventilation function is required. In northwest and southwest regions the farmers store grain mainly as rations and feed grain, which needs a long-time storage for nearly one year or more [6]. Therefore, the storage requirements are different.
4.2 Developing the Grain Storage Facilities for Large Rural Households Is Needed

Because of the needs of the farmers with large-scale production after the land transfer in every region, the steel granary with a storage capacity of 100 to 300 tons and its supporting grain drying and cleaning equipments should be researched and developed as soon as possible.

4.3 The Guidance and Trainning Work of the Grain Storage Should Be Carried out for Farmer's Grain Storage

The food department should take advantage of the technology to understand farmer's grain storage varieties, quantity, quality, and other information, and carry out the technical guidance and trainning service of the grain storage. Then we need to gradually establish the archival information system of exemplary farmers in order to expand the coverage of scientific grain storage, and to emphasize on $R \& D$, training, and application convergence of farmer's scientific grain storage technology. We shall improve the guidance and service way, and try best to carry out the farmer-benefit project.

4.4 It Is Needed to Increase the Product Quality and Create the Product Brand to Gradually Realize the Market-Oriented Production and Sales

The farmer's grain storage facilities manufacturing enterprises should increase the research efforts, strengthen the quality control, optimize the production process. Only with the product quality certification, good after-sales service and reasonable costs could make the famous product brand in farmers' mind, and then the market-oriented production and sales of farmer's grain storage facilities would be realized, with the assistant of the demonstration and promotion by government subsidies.

\section{Acknowledgment}

This study is supported by the "Special Fund for 

and Facilities for Chinese Farmers

Grain-scientific Research in the Public Interest”. The name of the project is "The study on the grain storage technologies and facilities for farmers in Jilin province of China”, the Project No. is 201313003-02-3.

\section{References}

[1] Wang, H. 2012. "The Current Situation of Chinese Farmer's Grain Storage.” Science and Technology of Cereals, Oils and Food 2: 58-60.

[2] Kang, X., and Zhang, X. 2008. "The Factors Influencing the Loss of Our Country Farmer Storage.” Grain Storage 4: 53-4.

[3] NDRC. 2011. “'Twelve Five’ Special Construction Plan on Farmer's Scientific Grain Storage.” National Development and Reform Commission Trade [2011], No. 587.

[4] Dong, W., and Chen, Zh. B. 2013. “'Twelve Five' Science and Technology Project Increases Our Food Production Continually.” Journal of Agricultural Science and Technology 4: 78-83.

[5] Food Engineering Construction Industry Standards in People's Republic of China. 2009. "Standard for Small-Scale Farm Bin Comstruction.” LS/T8005-2009.

[6] Zhao, Y., Wang, R. L., and Zhang, H. 2011. "Farmer's Grain Storage Technology Requirements and Countermeasures for Huang-huai-hai Area.” Grain Science and Technology and Economy 6: 20-2. 